\title{
Performance evaluation of bullock cart on various roads using various loading materials
}

\section{D.S. KARALE, U.S. KANKAL, S.H. THAKARE AND V. P. KHAMBALKAR}

Received : 18.12.2015; Revised : 01.03.2016; Accepted : 15.03.2016

See end of the Paper for authors' affiliation

Correspondence to :

\section{U.S. KANKAL}

Department of Farm Power and Machinery, Dr. Panjabrao Deshmukh Krishi Vidyapeeth, AKOLA (M.S.) INDIA

Email : uskankal@gmail.com
- ABSTRACT : This paper covers work carried out at Department of Farm Power and Machinery, Dr. PDKV, Akola. This paper discussed about the performance of the exiting bullock cart on various roads by using the different kind of materials. Drawbar test, track test and haulage test were carried and evaluated the performance of bullock cart. It was found that the pull increased as the laden mass of cart increased on various kinds of roads with the different types of loading materials. The forward speed decreased with continuous work as the laden mass of cart increased on various kinds of roads with the different types of loading materials. The wheel slippage increased as pull increased with laden mass of cart increased for various type of roads. It was observed that the bullock could pull one tonne load at a forward speed of 2 to $3 \mathrm{~km} / \mathrm{hr}$ with continuous work of $3 \mathrm{hrs}$. At turning it needs to reduce speed of travel and more attention should give by operator, when cart is fully loaded in order to avoid accident.

- KEY WORDS : Bullock cart, Comfort, Drawbar test, Haulage test, Performance track test

— HOW TO CITE THIS PAPER : Karale, D.S., Kankal, U.S., Thakare, S.H. and Khambalkar, V.P. (2016). Performance evaluation of bullock cart on various roads using various loading materials. Internat. J. Agric. Engg., 9(1) : 62-68. 